\title{
1 Severity of thermal burn injury is associated with systemic neutrophil activation
}

3 Maria Laggner, ${ }^{1,2}$ Marie-Therese Lingitz, ${ }^{3}$ Dragan Copic, ${ }^{1,2}$ Martin Direder, ${ }^{1,2}$ Katharina Klas, ${ }^{1,2}$

4 Daniel Bormann, ${ }^{1,2}$ Alfred Gugerell, ${ }^{1,2}$ Bernhard Moser, ${ }^{1}$ Christine Radtke, ${ }^{4}$ Stefan Hacker, ${ }^{4,5}$

5 Michael Mildner, ${ }^{6}$ Hendrik Jan Ankersmit, ${ }^{1,2, \S^{*}}$ Thomas Haider $^{7, \S *}$

6

$7 \quad{ }^{1}$ Department of Thoracic Surgery, Medical University of Vienna, 1090 Vienna, Austria

$8 \quad{ }^{2}$ Laboratory for Cardiac and Thoracic Diagnosis and Regeneration, 1090 Vienna, Austria

$9{ }^{3}$ Division of General Anesthesia and Intensive Care Medicine, Department of Anesthesia,

10 Critical Care and Pain Medicine, Medical University of Vienna, 1090 Vienna, Austria

$11{ }^{4}$ Department of Plastic, Reconstructive and Aesthetic Surgery, Medical University of Vienna,

121090 Vienna, Austria

135 Department of Plastic, Reconstructive and Aesthetic Surgery, Landesklinikum Wiener

14 Neustadt, 2700 Wiener Neustadt, Austria

$15{ }^{6}$ Department of Dermatology, Medical University of Vienna, 1090 Vienna, Austria

$16{ }^{7}$ Department of Orthopedics and Trauma Surgery, Medical University of Vienna, 1090 Vienna,

17 Austria

$18 \S$ contributed equally

$19 *$ corresponding authors

21 Hendrik Jan Ankersmit

22 Department of Thoracic Surgery, Medical University of Vienna

23 Waehringer Guertel 18-20, 1090 Vienna, Austria 
medRxiv preprint doi: https://doi.org/10.1101/2021.10.07.21264679; this version posted October 7, 2021. The copyright holder for this preprint (which was not certified by peer review) is the author/funder, who has granted medRxiv a license to display the preprint in perpetuity. It is made available under a CC-BY-NC-ND 4.0 International license .

24 phone: $+43-(0) 1-40400-67770$

25 e-mail: hendrik.ankersmit@meduniwien.ac.at

27 Thomas Haider

28 Department of Orthopedics and Trauma Surgery, Medical University of Vienna, Vienna, Austria

29 Waehringer Guertel 18-20, 1090 Vienna, Austria

30 phone: $+43-(0) 1-40400-59010$

31 fax: +43-(0)1-40400-59490

32 e-mail: thomas.a.haider@meduniwien.ac.at

34 Short Title: NETosis in burn injury

35 Key Words: burn injury, NETosis, neutrophil activation, citrullinated histone H3, neutrophil

36 elastase, myeloperoxidase, complement C3a, SOFA score, APACHE II score, ABSI score, $3^{\text {rd }}$

37 degree burn, inhalation trauma.

\section{Abstract}

\section{Objectives}

42 Burn injuries elicit a unique and dynamic stress response which can lead to burn injury

43 progression. Though neutrophils represent crucial players in the burn-induced immunological

44 events, the dynamic secretion pattern and systemic levels of neutrophil-derived factors have not

45 been investigated in detail so far.

\section{Methods}


medRxiv preprint doi: https://doi.org/10.1101/2021.10.07.21264679; this version posted October 7, 2021. The copyright holder for this preprint (which was not certified by peer review) is the author/funder, who has granted medRxiv a license to display the preprint in perpetuity.

It is made available under a CC-BY-NC-ND 4.0 International license .

47 Serum levels of neutrophil elastase (NE), myeloperoxidase (MPO), citrullinated histone H3

48 (CitH3), and complement factor C3a were quantified in burn victims over 4 weeks post injury.

49 Furthermore, the potential association with mortality, degree of burn injury, and inhalation

50 trauma was evaluated. In addition, leukocyte, platelet, neutrophil, and lymphocyte counts were

51 assessed. Lastly, we analyzed the association of neutrophil-derived factors with clinical severity

52 scoring systems.

\section{Results}

54 Serum levels of NE, MPO, CitH3, and C3a were remarkably elevated in burn victims compared

55 to healthy controls. Leukocyte and neutrophil counts were significantly increased on admission

56 day and day 1, while relative lymphocytes were decreased in the first 7 days post burn trauma.

57 Though neutrophil-derived factors did not predict mortality, patients suffering from $3^{\text {rd }}$ degree

58 burn injuries displayed increased CitH3 and NE levels. Accordingly, CitH3 and NE were

59 elevated in cases with higher abbreviated burn severity indices (ABSI).

\section{Conclusions}

61 Taken together, our data suggest a role for neutrophil activation and NETosis in burn injuries and

62 burn injury progression. Targeting exacerbated neutrophil activation might represent a new

63 therapeutic option for severe cases of burn injury.

\section{Introduction}

66 Burn injury is an umbrella term for a trauma, most commonly affecting the skin or lung, caused

67 by a variety of external challenges, such as thermal extremes, deleterious radiation, alkaline and

68 acidic chemicals, or excessive friction (1). The respective cause and burn degree further dictate

69 clinical management, such as surgical intervention and moist rewarming following heat- and

70 cold-induced injuries, respectively. In spite of the development of new therapeutic approaches, 
medRxiv preprint doi: https://doi.org/10.1101/2021.10.07.21264679; this version posted October 7, 2021. The copyright holder for this preprint (which was not certified by peer review) is the author/funder, who has granted medRxiv a license to display the preprint in perpetuity.

It is made available under a CC-BY-NC-ND 4.0 International license .

71 burn injuries are still associated with a high mortality rate, most commonly resulting from

72 multiple organ failure, sepsis, and respiratory complications (2). Morbidity and mortality can be

73 increased up to 10 years after the initial insult (3).

75 Burn trauma elicits a unique systemic stress response characterized by increased metabolism and

76 inflammation (4). The early systemic inflammatory response syndrome (SIRS) is characterized

77 by pro-inflammatory cytokines, such as interleukin 6 (IL-6), IL-8, and tumor necrosis factor

78 alpha $(\mathrm{TNF} \alpha)$ and usually lasts for several days $(5,6)$. Later, the milieu is shifted towards an

79 anti-inflammatory response syndrome (AIRS), where the immunosuppressant mediators TGF $\beta 1$,

80 and IL-10 prevail (6). Though inflammation is inherent and indispensable for normal wound

81 healing (7), burn injuries can induce a state of distorted inflammatory response which can persist

82 up to several years (8) and which can ultimately lead to host tissue damage and organ

83 dysfunction. Various factors orchestrate early immune reactions, such as the amount of affected

84 body surface area, burn depth and cause, inhalation injury, patient age, and chronic medical

85 conditions (9). Neutrophils (10) and macrophages (11) are early key players infiltrating the burn-

86 injured area. Though these immune cells are readily activated by burn injury-induced damage-

87 associated molecular patterns (DAMPs), macrophage antigen presentation and neutrophil-

88 mediated killing of pathogens have been shown to be diminished following burn injury $(12,13)$,

89 leading to increased susceptibility to infections. While immunological hyper-activation entails

90 tissue damage, exaggerated immunosuppression predisposes to infections (14). Hence, a delicate

91 balance of immunomodulators determines clinical outcome in burn injuries.

92 A commonly observed phenomenon of burn victims is secondary burn progression (15). While

93 tissue necrosis and ischemia are immediate results of burn injury, tissue damage is often 
medRxiv preprint doi: https://doi.org/10.1101/2021.10.07.21264679; this version posted October 7, 2021. The copyright holder for this preprint (which was not certified by peer review) is the author/funder, who has granted medRxiv a license to display the preprint in perpetuity.

It is made available under a CC-BY-NC-ND 4.0 International license .

94 aggravated long after the initial trauma. Formation of red blood cell aggregates and

95 microthrombi and subsequent occlusion of the microvasculature have been identified as the

96 underlying cause of burn progression (16). Though secondary burn progression substantially

97 promotes tissue damage, its role in the post injury tissue response is often underestimated.

99 Neutrophils are implicated in the host defense against pathogens, whereby antimicrobial activity

100 is exerted by phagocytosis, release of effector molecules, and formation of neutrophil

101 extracellular traps (NETs) (17). Activated protein-arginine deiminase 4 (PAD4) catalyzes

102 citrullination of histones, which results in chromatin decondensation. Granule proteins, such as

103 myeloperoxidase (MPO) and neutrophil elastase (NE), further promote DNA de-compaction and

104 intracellular DNA together with granule proteins are released following plasma membrane

105 rupture $(18,19)$. It was further demonstrated that neutrophils contain intracellular stores of C3a

106 (20), which might be self-synthesized or absorbed from the serum (21). Moreover, C3a was

107 reported to induce neutrophil activation (22). A role for neutrophils in coagulation and

108 microvascular obstruction has been described at several occasions (23-27). The amount of

109 neutrophil-derived circulating, free DNA was proposed as a predictor of mortality in severely

110 burnt patients (28) and elevated human neutrophil elastase DNA and nucleosomes were detected

111 in burn and sepsis patients (29). Though previous studies have reported a role for neutrophils and

112 NETs in burn injury $(30,31)$, systemic surrogate markers indicating NETosis have not been

113 comprehensively studied so far. Our group was previously able to show activation of the soluble

114 suppressor of tumorigenicity 2 (sST2) / IL-33 axis in sepsis (32) as well as thermal burn injury

115 (33) and found increased soluble ST2 to be a predictor of mortality. In the current study, we 
medRxiv preprint doi: https://doi.org/10.1101/2021.10.07.21264679; this version posted October 7, 2021. The copyright holder for this preprint (which was not certified by peer review) is the author/funder, who has granted medRxiv a license to display the preprint in perpetuity.

It is made available under a CC-BY-NC-ND 4.0 International license .

116 aimed to delineate the dynamics of neutrophil-derived immunomodulators to deepen our

117 understanding of NETosis in the post-burn injury immune response.

118

\section{Materials and methods}

120 Ethical statements

121 This study was approved by the institutional review board of the Medical University of Vienna

122 (Vienna, Austria) (vote 593/2011) and was conducted in accordance with the Declaration of

123 Helsinki and applicable local regulations. Written informed consent was obtained from all 124 donors.

125

126 Patient cohort and serum sample acquisition

127 Samples used in the current study have already been analyzed for sST2 and IL-33 (33).

128 Patients $>18$ years who were admitted within 24 hours post trauma to burn intensive care unit

129 and presented with a burn injury covering $>10 \%$ of the total body surface area (TBSA) at

130 primary survey were included in this study (Table 1). Patients with chronic infectious diseases or

131 autoimmune disorders were excluded. Eight healthy volunteers served as controls.

132 Sera were obtained daily within the first week after admission, and weekly up to day 28 after

133 admission. For controls, samples were obtained in the same manner. Whole blood was incubated

134 for thirty minutes at ambient temperature and centrifuged at 2850 relative centrifugal force for 17

135 minutes. Sera were separated and cryopreserved below $-70^{\circ} \mathrm{C}$.

136 Intensive care management including fluid resuscitation was performed according to institutional

137 guidelines and was not affected by this study. Inhalation trauma was assessed on primary survey 
medRxiv preprint doi: https://doi.org/10.1101/2021.10.07.21264679; this version posted October 7, 2021. The copyright holder for this preprint (which was not certified by peer review) is the author/funder, who has granted medRxiv a license to display the preprint in perpetuity.

It is made available under a CC-BY-NC-ND 4.0 International license .

138 and deemed present in cases of visible signs of thermal injury within the upper airway. Mortality

139 was defined as all-cause in-hospital mortality.

\section{Analyte quantifications}

142 Serum MPO, CitH3, NE, C3a, and lactadherin (milk fat globulin protein E8, MFG-E8) were

143 quantified by enzyme-linked immunosorbent assay (ELISA) using commercially available kits as

144 recommended by the manufacturers (human MPO, human neutrophil elastase, human MFG-E8

145 Immunoassay Quantikine, all R\&D Systems, Bio-Techne, Minneapolis, MN, USA; human

146 CitH3, clone 11D3, Cayman Chemical, Ann Arbor, MI, USA; human complement C3a,

147 Invitrogen, Thermo Fisher Scientific, Waltham, MA, USA). Colorimetric measurements were

148 performed using Tecan F50 infinite microplate reader (Tecan Group, Männedorf, Switzerland)

149 with Magellan software (version 7.2, Tecan). Analyte concentrations were determined by

150 external standard curves.

151

152 Laboratory measurements of clinical parameters

153 Complete blood counts were determined during routine clinical tests and reference values were

154 adopted from in-house reference ranges. Sequential organ failure assessment (SOFA) score (34),

155 acute physiology and chronic health evaluation II (APACHE II) score (35), and abbreviated burn

156 severity index (ABSI) (36) were assessed on the day of admission. Median values of severity

157 scores were used to assign values to low and high groups. As the SOFA score of our study

158 population displayed a median of 6.5 , we chose $\leq 6$ and $\geq 7$ as cut-off values.

160 Statistical analyses 
medRxiv preprint doi: https://doi.org/10.1101/2021.10.07.21264679; this version posted October 7, 2021. The copyright holder for this preprint (which was not certified by peer review) is the author/funder, who has granted medRxiv a license to display the preprint in perpetuity.

It is made available under a CC-BY-NC-ND 4.0 International license .

161 Data were statistically evaluated and visualized using SPSS Statistics (version 25, IBM, Armonk,

162 NY, USA) and GraphPad Prism (version 5.01, GraphPad Software Inc., La Jolla, CA, USA).

163 Continuous variables were compared by the Mann-Whitney test. One-way ANOVA and multiple

164 comparison post hoc tests with Sidak's or Dunnett's correction were calculated. For correlation

165 analysis, Pearson's correlation coefficients were calculated. Data are presented as arithmetic

166 means \pm standard error of the mean.

168 Results

169 Neutrophil-derived factors are systemically elevated following burn injury

170 To study the role of burn injury-induced NETosis, we tracked the neutrophil-derived factors

171 MPO, CitH3, NE, and C3a in sera of burn victims up to 4 weeks post trauma. We found that

172 NETosis-associated factors were significantly increased compared to healthy controls (Figure 1).

173 MPO was remarkably increased in the early days post burn injury (Figure 1A). While CitH3 did

174 not differ from controls on admission day and day 1, serum CitH3 concentrations showed a

175 delayed increase, peaking on day 4 post admission (Figure 1B), indicating a potential 'second

176 burn' hit. Intriguingly, NE levels were elevated on admission day and in the early stress response

177 to burn trauma before approximating levels detected in healthy controls (Figure 1C). Serum C3a

178 was strongly elevated in burn victims compared to controls (Figure 1D). To test a potential

179 connection between systemic C3a levels and liver parameters in burn victims, we furthermore

180 assessed gamma-glutamyltransferase $(\gamma-\mathrm{GT})$ levels. $\gamma$-GT started increasing 2 weeks post injury,

181 but did not correlate with C3a (Supplemental Figure S1). Since lactadherin promoted survival of

182 septic rats (37) and lactadherin prevented coagulopathy following traumatic brain injury (38), we

183 addressed the question whether lactadherin might also be involved in the burn injury-induced 
medRxiv preprint doi: https://doi.org/10.1101/2021.10.07.21264679; this version posted October 7, 2021. The copyright holder for this preprint (which was not certified by peer review) is the author/funder, who has granted medRxiv a license to display the preprint in perpetuity.

It is made available under a CC-BY-NC-ND 4.0 International license .

184 immune response. When assessing serum lactadherin levels, we observed no difference between

185 burn victims and healthy controls (Supplemental Figure S2). We furthermore aimed to

186 investigate the relationship between neutrophil-derived factors and found a positive correlation

187 between MPO and NE, but not between CitH3 and NE or between CitH3 and MPO

188 (Supplemental Figure S3). These data suggest a role for NETosis in the systemic post burn injury

189 immune response.

191 Burn injury induced leukocytosis and relative lymphopenia

192 Next, we assessed immune cell status in our patient cohort. We found that absolute leukocyte

193 and neutrophil numbers were strongly increased in burn victims (Figures 2A, C, \& D). In detail,

194 cell numbers were elevated in the early days post injury, decreased within the first week before

195 incrementing again. While platelet counts of burn victims were below those of healthy controls

196 within the first week post injury, we observed a remarkable increase in platelet numbers 3 weeks

197 post trauma (Figure 2B). These data suggest a delayed, immunological 'second hit' and burn

198 injury progression even weeks after primary injury. Absolute lymphocyte counts showed no

199 difference between controls and burn victims, while relative lymphocyte levels were strongly

200 decreased in the first 7 days after injury (Figures $2 \mathrm{E} \& \mathrm{~F}$ ). Together, these data indicate an

201 intricate systemic effect of burn injury on immune cell status.

202

$203 \mathbf{3}^{\text {rd }}$ degree burns are associated with increased CitH3 and NE

204 We aimed to test whether our set of serum markers might be associated with mortality, inhalation

205 trauma, or $3^{\text {rd }}$ degree burn injury. Our battery of neutrophil-derived factors did not predict 206 mortality, and C3a was even strongly reduced in deceased burn victims (Supplemental Figure 
medRxiv preprint doi: https://doi.org/10.1101/2021.10.07.21264679; this version posted October 7, 2021. The copyright holder for this preprint (which was not certified by peer review) is the author/funder, who has granted medRxiv a license to display the preprint in perpetuity.

It is made available under a CC-BY-NC-ND 4.0 International license .

207 S4). We furthermore compared burn victims with inhalation trauma to those without respiratory

208 damage and observed no effect of lung injury on serum levels of neutrophil-derived factors

209 (Supplemental Figure S5). Similarly, serum MPO levels displayed no difference when

210 comparing $3^{\text {rd }}$ degree burn victims with patients suffering from $1^{\text {st }}$ and $2^{\text {nd }}$ degree burns (Figure

$2113 \mathrm{~A})$. By comparison, we observed elevated serum CitH3 and NE levels on days 3 and 4 of $3^{\text {rd }}$

212 degree burns compared to first and second degree burns (Figures 3B \& C). Of note, the delayed

213 increase of serum CitH3 3 and 4 days post injury were exclusively detected in $3^{\text {rd }}$ degree burns.

214 Surprisingly, C3a levels were strongly reduced in higher degree burns on day 3 (Figure 3D).

215 These findings suggest that the degree of burn injury determines the extent of neutrophil

216 activation and NETosis.

218 CitH3 is elevated in patients with higher severity scores

219 We sought to determine whether neutrophil-derived factors were associated with clinical severity

220 scoring systems and dichotomized SOFA, APACHE II, and ABSI scores into low and high

221 values. We observed increased MPO and CitH3 levels in patients with APACHE II scores above

22218 (Supplemental Figure S6) and NE was significantly higher in SOFA scores $\geq 7$ (Supplemental

223 Figure S7). Intriguingly, CitH3 and NE levels were elevated in patients with ABSI scores above

224 9, while MPO and C3a showed no difference (Figure 4). These data suggest that specific

225 NETosis-associated factors are elevated in more severe burns. 
medRxiv preprint doi: https://doi.org/10.1101/2021.10.07.21264679; this version posted October 7, 2021. The copyright holder for this preprint (which was not certified by peer review) is the author/funder, who has granted medRxiv a license to display the preprint in perpetuity.

It is made available under a CC-BY-NC-ND 4.0 International license .

228 Finally, we investigated whether the burn injury-induced alterations in immune cell levels were

229 associated with severity of burn injury. Therefore, cell counts were compared between $3^{\text {rd }}$ degree

230 and lower degree burn victims and furthermore between patients with higher and lower clinical

231 severity scores. A trend towards increased leukocyte and neutrophil counts in more severe cases

232 was found on admission day, while no difference in platelet and relative neutrophil counts was

233 observed (Supplemental Figures S8 - S11). Absolute and relative lymphopenia was more

234 pronounced in the early days following burn injury when comparing low versus high SOFA

235 scores (Supplemental Figure S10), indicating that immune cell counts are time- and score-

236 dependent.

\section{Discussion}

239 Burn injuries trigger a complex immune response characterized by a unique cytokine secretion

240 pattern and immune cell activation. Exaggerated burn-induced immune activation can lead to

241 tissue damage and organ dysfunction, while immunosuppression can predispose to infectious

242 diseases. Activation of neutrophils and secretion of neutrophil-derived factors add another piece

243 to the complex picture of immunological reactions in response to burn injuries. We were the first

244 to track systemic levels of neutrophil-derived immunomodulators up to 4 weeks post trauma and

245 were able to demonstrate that the NETosis surrogate markers MPO, CitH3, NE, and C3a were

246 increased in burn victims compared to healthy controls. Several studies have already suggested a

247 role for neutrophils in the immune response elicited by burn injuries. Circulating DNA in plasma

248 has been identified as a prognostic marker for mortality and an early biomarker of sepsis in burn-

249 injured patients $(12,28)$, though free DNA does not exclusively originate from NETs (39) and is

250 therefore considered a rather indirect evidence of neutrophil involvement. Further studies 
medRxiv preprint doi: https://doi.org/10.1101/2021.10.07.21264679; this version posted October 7, 2021. The copyright holder for this preprint (which was not certified by peer review) is the author/funder, who has granted medRxiv a license to display the preprint in perpetuity.

It is made available under a CC-BY-NC-ND 4.0 International license .

251 investigated more neutrophil-specific factors. Bacteriostatic effects of topically administered

252 MPO were demonstrated in Staphylococcus aureus-infected burn wounds (40) and increased

253 MPO activity was observed following burn injury in rats (41). Intriguingly, burn injury reduced

254 NETosis, indicated by diminished CitH3 levels, via pulmonary immunosuppression (31). A role

255 for NE in the proteolytic degradation of fibronectin in burn wound fluids (42) and in burn-blast-

256 induced lung injury in rats (43) has been reported and inhibiting NE activity exerted

257 cytoprotective effects (43).These studies investigated local levels of MPO, CitH3, and NE in

258 burn wounds, burn fluids, or lung tissues. Systemic concentrations of these factors have not been

259 comprehensively described to date. Our data with a 4 week follow up time post burn injury

260 therefore add valuable information to the role of NETosis in the burn injury-induced stress

261 response.

262 We detected increased serum concentrations of complement C3a in burn-injured patients

263 compared to controls. Elevated C3a levels have already been reported previously in plasma of

264 burn victims (44) and in subdermal tissues of second-degree thermal wounds (45). Interestingly,

265 expression of complement receptors on neutrophils was increased following burn injury (46) and

266 it was previously demonstrated that neutrophilic elastase promotes complement amplification

267 (47). Hence, an intricate crosstalk between the complement system and neutrophils occurs in the

268 immune response to burn injury. Though intracellular stores of C3a have been found in

269 neutrophils (20), numerous other cell types and tissues, such as the liver (48), are conceivable to

270 contribute to serum C3a levels post burn injury. Our C3a levels did not correlate with $\gamma$-GT,

271 indicating that complement activation is not associated with liver disease in our settings.

272 Delineating the exact cellular origin of systemic C3a in burn victims will be subject of future 273 studies. 
medRxiv preprint doi: https://doi.org/10.1101/2021.10.07.21264679; this version posted October 7, 2021. The copyright holder for this preprint (which was not certified by peer review) is the author/funder, who has granted medRxiv a license to display the preprint in perpetuity.

It is made available under a CC-BY-NC-ND 4.0 International license .

275 We observed remarkably increased absolute leukocyte counts in burn victims compared to

276 healthy controls, while absolute lymphocyte counts remained largely unaltered. In addition,

277 absolute neutrophil levels were strongly increased post burn injury. These data are in line with

278 data reported by Mulder et al. (49) and it is tempting to speculate that the elevated neutrophil

279 amounts detected in our patient cohort might serve as a potential cellular source for MPO, CitH3,

280 NE, and C3a. We furthermore observed that the increase of absolute leukocyte and neutrophil

281 counts was even more pronounced in more severe cases. Intriguingly, relative lymphocyte levels

282 were remarkably decreased in patients with burn injury and lower in patients with higher SOFA

283 score. Lymphopenia has already been reported in septic and burn victims, which might

284 contribute to post-injury immunosuppression, morbidity, and mortality (50-52). Platelet levels

285 were decreased in the early stress response and re-elevated starting 14 days after burn injury.

286 These dynamics are in accordance with previous reports, where a sustained pro-coagulant state

287 of burn patients was described (53). Together, these data connect the systemic factors with

288 clinical blood parameters and contribute to a better understanding of the cellular and molecular

289 processes in the concerted burn injury response.

291 Microvascular obstruction was reported as the leading cause of burn injury progression and red

292 blood cell aggregates, microthrombi, and ischemia have been described to promote secondary

293 tissue damage (16). NETs serve as a scaffold for platelets, induce platelet aggregation and

294 coagulation $(23,24)$ and have furthermore been shown to exert pro-coagulant activities in sepsis

295 (25). Moreover, neutrophil activation and CitH3 were induced by myocardial

296 ischemia/reperfusion injury and showed pro-thrombotic and cytotoxic features, while eliminating 
medRxiv preprint doi: https://doi.org/10.1101/2021.10.07.21264679; this version posted October 7, 2021. The copyright holder for this preprint (which was not certified by peer review) is the author/funder, who has granted medRxiv a license to display the preprint in perpetuity.

It is made available under a CC-BY-NC-ND 4.0 International license .

297 NETs by DNase I treatment exerted cardio-protective effects (26). In addition, elevated CitH3

298 levels were reported in various inflammatory conditions with a role of microvascular thrombosis

299 (27, 54). Though lactadherin levels remain unaltered, we observed systemic CitH3 elevation 2 -

3005 days post burn injury and detected abnormal immune cell counts even several weeks after burn

301 injury. These findings corroborate the concept of burn injury progression following initial

302 damage. We hypothesize that injury-induced elevation of neutrophil counts and concomitant

303 neutrophil activation contribute to burn injury progression. NETosis and systemic neutrophil-

304 derived factors are induced in the course of a delayed immunological response, provoke

305 microvascular obstruction, and thereby promote secondary tissue damage.

307 Our data revealed that $3^{\text {rd }}$ degree burns showed higher CitH3 and NE levels and these results are

308 in line with the clinical severity score ABSI, where cases with higher scoring displayed increased

309 CitH3 and NE. These data suggest that the severity of burn injury dictates the level of neutrophil

310 activation. Intriguingly, patients succumbing to burn trauma did not display elevated neutrophil-

311 derived immunomodulators. While we found elevated CitH3 and NE levels in patients with

312 higher degree and severity burns, future studies with larger samples sizes will be required to

313 determine whether elevated NETosis-associated factors might serve as a prognostic factor for

314 mortality following severe burn injury. Moreover, no difference between burn victims suffering

315 from inhalation trauma compared to burn-injured patients without inhalation trauma was

316 observed. Neutrophilia in the bronchoalveolar space upon inhalation trauma has been described

317 and attenuating neutrophil recruitment improved histopathology scores and bacterial clearance

318 (55). Though NETosis markers were not related to inhalation trauma in our patient collective, a

319 role for burn-associated lung injury in neutrophil activation cannot be entirely ruled out (56). 
medRxiv preprint doi: https://doi.org/10.1101/2021.10.07.21264679; this version posted October 7, 2021. The copyright holder for this preprint (which was not certified by peer review) is the author/funder, who has granted medRxiv a license to display the preprint in perpetuity.

It is made available under a CC-BY-NC-ND 4.0 International license .

321 In spite of our best efforts, this study has certain limitations. Though 32 burn victims were

322 initially included, the number of available specimen declined over time as patients either

323 succumbed to their injury or were discharged from the hospital. Future studies with higher

324 sample numbers will be required to fully elucidate the role of neutrophil-derived factors in the

325 burn injury response. Our set of neutrophil-derived factors serves as a surrogate machinery to

326 assess NETosis. Further investigations are necessary to provide more direct evidence of systemic

327 NETosis in sera of burn victims.

328

329 Clinical management of burn victims involves fluid resuscitation, burn wound coverage,

330 supportive care, and rehabilitation. Targeting neutrophil function in post burn injury might serve

331 as an alternative treatment option in severe cases with exacerbated neutrophil activation.

332 Determining the full therapeutic potential of NETosis inhibition following burn trauma will merit

333 future investigations.

334

335

336

\section{References}

339 1. Association AB. National Burn Repository 2019 Update: Report of Data from 2009 to 340 2018. American Burn Association: Chicago, IL, USA. 2019.

341 2. Brusselaers N, Monstrey S, Vogelaers D, Hoste E, Blot S. Severe burn injury in Europe: 342 a systematic review of the incidence, etiology, morbidity, and mortality. Crit Care. 343 2010;14(5):R188.

344 3. Mason SA, Nathens AB, Byrne JP, Diong C, Fowler RA, Karanicolas PJ, et al. Increased 345 Rate of Long-term Mortality Among Burn Survivors: A Population-based Matched Cohort 346 Study. Ann Surg. 2019;269(6):1192-9. 
medRxiv preprint doi: https://doi.org/10.1101/2021.10.07.21264679; this version posted October 7, 2021. The copyright holder for this preprint (which was not certified by peer review) is the author/funder, who has granted medRxiv a license to display the preprint in perpetuity. It is made available under a CC-BY-NC-ND 4.0 International license .

4. Guillory AN, Porter C, Suman OE, Zapata-Sirvent RL, Finnerty CC, Herndon DN. Modulation of the hypermetabolic response after burn injury. Total burn care. 2018:301-6. e3. 5. Agay D, Andriollo-Sanchez M, Claeyssen R, Touvard L, Denis J, Roussel AM, et al. Interleukin-6, TNF-alpha and interleukin-1 beta levels in blood and tissue in severely burned rats. Eur Cytokine Netw. 2008;19(1):1-7.

6. Ravat F, Payre J, Peslages P, Fontaine M, Sens N. [Burn: An inflammatory process]. Pathol Biol (Paris). 2011;59(3):e63-72.

7. Serra MB, Barroso WA, da Silva NN, Silva SDN, Borges ACR, Abreu IC, et al. From Inflammation to Current and Alternative Therapies Involved in Wound Healing. Int J Inflam. 2017;2017:3406215.

8. Jeschke MG, Gauglitz GG, Kulp GA, Finnerty CC, Williams FN, Kraft R, et al. Longterm persistance of the pathophysiologic response to severe burn injury. PLoS One. 2011;6(7):e21245.

9. Jeschke MG, van Baar ME, Choudhry MA, Chung KK, Gibran NS, Logsetty S. Burn injury. Nat Rev Dis Primers. 2020;6(1):11.

10. Lateef Z, Stuart G, Jones N, Mercer A, Fleming S, Wise L. The Cutaneous Inflammatory Response to Thermal Burn Injury in a Murine Model. Int J Mol Sci. 2019;20(3).

11. Shallo H, Plackett TP, Heinrich SA, Kovacs EJ. Monocyte chemoattractant protein-1 (MCP-1) and macrophage infiltration into the skin after burn injury in aged mice. Burns. 2003;29(7):641-7.

12. Hampson P, Dinsdale RJ, Wearn CM, Bamford AL, Bishop JRB, Hazeldine J, et al. Neutrophil Dysfunction, Immature Granulocytes, and Cell-free DNA are Early Biomarkers of Sepsis in Burn-injured Patients: A Prospective Observational Cohort Study. Ann Surg. 2017;265(6):1241-9.

13. Kupper TS, Green DR, Durum SK, Baker CC. Defective antigen presentation to a cloned $\mathrm{T}$ helper cell by macrophages from burned mice can be restored with interleukin-1. Surgery. 1985;98(2):199-206.

14. Moins-Teisserenc H, Cordeiro DJ, Audigier V, Ressaire Q, Benyamina M, Lambert J, et al. Severe Altered Immune Status After Burn Injury Is Associated With Bacterial Infection and Septic Shock. Front Immunol. 2021;12:586195.

15. Tobalem M, Harder Y, Rezaeian F, Wettstein R. Secondary burn progression decreased by erythropoietin. Crit Care Med. 2013;41(4):963-71.

16. Clark RAF, Fenner J, Sasson A, McClain SA, Singer AJ, Tonnesen MG. Blood vessel occlusion with erythrocyte aggregates causes burn injury progression-microvasculature dilation as a possible therapy. Exp Dermatol. 2018;27(6):625-9.

17. Rios-Lopez AL, Gonzalez GM, Hernandez-Bello R, Sanchez-Gonzalez A. Avoiding the trap: Mechanisms developed by pathogens to escape neutrophil extracellular traps. Microbiol Res. 2021;243:126644.

18. Brinkmann V, Reichard U, Goosmann C, Fauler B, Uhlemann Y, Weiss DS, et al. Neutrophil extracellular traps kill bacteria. Science. 2004;303(5663):1532-5.

19. Fuchs TA, Abed U, Goosmann C, Hurwitz R, Schulze I, Wahn V, et al. Novel cell death program leads to neutrophil extracellular traps. J Cell Biol. 2007;176(2):231-41.

20. Liszewski MK, Kolev M, Le Friec G, Leung M, Bertram PG, Fara AF, et al. Intracellular complement activation sustains $\mathrm{T}$ cell homeostasis and mediates effector differentiation. Immunity. 2013;39(6):1143-57. 
medRxiv preprint doi: https://doi.org/10.1101/2021.10.07.21264679; this version posted October 7, 2021. The copyright holder for this preprint (which was not certified by peer review) is the author/funder, who has granted medRxiv a license to display the preprint in perpetuity. It is made available under a CC-BY-NC-ND 4.0 International license .

21. Elvington M, Liszewski MK, Bertram P, Kulkarni HS, Atkinson JP. A C3(H20) recycling pathway is a component of the intracellular complement system. J Clin Invest. 2017;127(3):970-81.

22. Norgauer J, Dobos G, Kownatzki E, Dahinden C, Burger R, Kupper R, et al. Complement fragment $\mathrm{C} 3 \mathrm{a}$ stimulates $\mathrm{Ca} 2+$ influx in neutrophils via a pertussis-toxin-sensitive G protein. Eur J Biochem. 1993;217(1):289-94.

23. Martinod K, Wagner DD. Thrombosis: tangled up in NETs. Blood. 2014;123(18):276876.

24. Massberg S, Grahl L, von Bruehl ML, Manukyan D, Pfeiler S, Goosmann C, et al. Reciprocal coupling of coagulation and innate immunity via neutrophil serine proteases. Nat Med. 2010;16(8):887-96.

25. Iba T, Miki T, Hashiguchi N, Tabe Y, Nagaoka I. Is the neutrophil a 'prima donna' in the procoagulant process during sepsis? Crit Care. 2014;18(4):230.

26. Savchenko AS, Borissoff JI, Martinod K, De Meyer SF, Gallant M, Erpenbeck L, et al. VWF-mediated leukocyte recruitment with chromatin decondensation by PAD4 increases myocardial ischemia/reperfusion injury in mice. Blood. 2014;123(1):141-8.

27. Zuo Y, Yalavarthi S, Shi H, Gockman K, Zuo M, Madison JA, et al. Neutrophil extracellular traps in COVID-19. JCI Insight. 2020;5(11).

28. Altrichter J, Zedler S, Kraft R, Faist E, Mitzner SR, Sauer M, et al. Neutrophil-derived circulating free DNA (cf-DNA/NETs), a potential prognostic marker for mortality in patients with severe burn injury. Eur J Trauma Emerg Surg. 2010;36(6):551-7.

29. Kaufman T, Magosevich D, Moreno MC, Guzman MA, D'Atri LP, Carestia A, et al. Nucleosomes and neutrophil extracellular traps in septic and burn patients. Clin Immunol. 2017;183:254-62.

30. Korkmaz HI, Ulrich MMW, Vogels S, de Wit T, van Zuijlen PPM, Krijnen PAJ, et al. Neutrophil extracellular traps coincide with a pro-coagulant status of microcirculatory endothelium in burn wounds. Wound Repair Regen. 2017;25(4):609-17.

31. Sakuma M, Khan MAS, Yasuhara S, Martyn JA, Palaniyar N. Mechanism of pulmonary immunosuppression: extrapulmonary burn injury suppresses bacterial endotoxin-induced pulmonary neutrophil recruitment and neutrophil extracellular trap (NET) formation. FASEB J. 2019;33(12):13602-16.

32. Brunner M, Krenn C, Roth G, Moser B, Dworschak M, Jensen-Jarolim E, et al. Increased levels of soluble ST2 protein and IgG1 production in patients with sepsis and trauma. Intensive Care Med. 2004;30(7):1468-73.

33. Hacker S, Dieplinger B, Werba G, Nickl S, Roth GA, Krenn CG, et al. Increased serum concentrations of soluble ST2 predict mortality after burn injury. Clin Chem Lab Med. 2018;56(12):2079-87.

34. Vincent JL, Moreno R, Takala J, Willatts S, De Mendonca A, Bruining H, et al. The SOFA (Sepsis-related Organ Failure Assessment) score to describe organ dysfunction/failure. On behalf of the Working Group on Sepsis-Related Problems of the European Society of Intensive Care Medicine. Intensive Care Med. 1996;22(7):707-10.

35. Knaus WA, Draper EA, Wagner DP, Zimmerman JE. APACHE II: a severity of disease classification system. Crit Care Med. 1985;13(10):818-29.

36. Tobiasen J, Hiebert JM, Edlich RF. The abbreviated burn severity index. Ann Emerg Med. 1982;11(5):260-2. 
medRxiv preprint doi: https://doi.org/10.1101/2021.10.07.21264679; this version posted October 7, 2021. The copyright holder for this preprint (which was not certified by peer review) is the author/funder, who has granted medRxiv a license to display the preprint in perpetuity. It is made available under a CC-BY-NC-ND 4.0 International license .

37. Miksa M, Dong D, Wu R, Ravikumar T, Wang P. Erhöhte Sterblichkeit von Mäusen mit Lactadherinmangel in einer Sepsis: Rolle Verminderter Phagozytose Apoptotischer Zellen. Zeitschrift für Geburtshilfe und Neonatologie. 2007;211(S 1):FV88.

38. Zhou Y, Cai W, Zhao Z, Hilton T, Wang M, Yeon J, et al. Lactadherin promotes microvesicle clearance to prevent coagulopathy and improves survival of severe TBI mice. Blood. 2018;131(5):563-72.

39. Kustanovich A, Schwartz R, Peretz T, Grinshpun A. Life and death of circulating cellfree DNA. Cancer Biol Ther. 2019;20(8):1057-67.

40. Guo R, Li S, Xia H, Feng Z, Tang Q, Peng C. Effects of Myeloperoxidase on MethicillinResistant Staphylococcus aureus-Colonized Burn Wounds in Rats. Adv Wound Care (New Rochelle). 2019;8(7):271-80.

41. Sehirli O, Sener E, Sener G, Cetinel S, Erzik C, Yegen BC. Ghrelin improves burninduced multiple organ injury by depressing neutrophil infiltration and the release of proinflammatory cytokines. Peptides. 2008;29(7):1231-40.

42. Grinnell F, Zhu M. Identification of neutrophil elastase as the proteinase in burn wound fluid responsible for degradation of fibronectin. J Invest Dermatol. 1994;103(2):155-61.

43. Chai JK, Cai JH, Deng HP, Zou XF, Liu W, Hu QG, et al. Role of neutrophil elastase in lung injury induced by burn-blast combined injury in rats. Burns. 2013;39(4):745-53.

44. Davis CF, Moore FD, Jr., Rodrick ML, Fearon DT, Mannick JA. Neutrophil activation after burn injury: contributions of the classic complement pathway and of endotoxin. Surgery. 1987;102(3):477-84.

45. Machens HG, Pabst A, Dreyer M, Gliemroth J, Gorg S, Bahlmann L, et al. C3a levels and occurrence of subdermal vascular thrombosis are age-related in deep second-degree burn wounds. Surgery. 2006;139(4):550-5.

46. Moore FD, Jr., Davis C, Rodrick M, Mannick JA, Fearon DT. Neutrophil activation in thermal injury as assessed by increased expression of complement receptors. N Engl J Med. 1986;314(15):948-53.

47. Fumia S, Goede JS, Fischler M, Luginbuhl A, Frick S, Fodor P, et al. Human F(ab')2containing immune complexes together with anti-hinge natural antibodies stimulate complement amplification in vitro and in vivo. Mol Immunol. 2008;45(10):2951-61.

48. Thorgersen EB, Barratt-Due A, Haugaa H, Harboe M, Pischke SE, Nilsson PH, et al. The Role of Complement in Liver Injury, Regeneration, and Transplantation. Hepatology. 2019;70(2):725-36.

49. Mulder PPG, Vlig M, Boekema B, Stoop MM, Pijpe A, van Zuijlen PPM, et al. Persistent Systemic Inflammation in Patients With Severe Burn Injury Is Accompanied by Influx of Immature Neutrophils and Shifts in T Cell Subsets and Cytokine Profiles. Front Immunol. 2020;11:621222.

50. Roth G, Moser B, Krenn C, Brunner M, Haisjackl M, Almer G, et al. Susceptibility to programmed cell death in T-lymphocytes from septic patients: a mechanism for lymphopenia and Th2 predominance. Biochem Biophys Res Commun. 2003;308(4):840-6.

51. Maldonado M, Venturoli A, Franco A, Nunez-Roldan A. Specific changes in peripheral blood lymphocyte phenotype from burn patients. Probable origin of the thermal injury-related lymphocytopenia. Burns. 1991;17(3):188-92.

52. Lebedev MY, Sholkina MN, Utkina TM, Vilkov SA, Korablev SB, Golubcova NV, et al. Immunophenotype of Peripheral Blood Lymphocytes in Patients with Burns. Russ J Immunol. 2001;6(1):47-54. 
medRxiv preprint doi: https://doi.org/10.1101/2021.10.07.21264679; this version posted October 7, 2021. The copyright holder for this preprint (which was not certified by peer review) is the author/funder, who has granted medRxiv a license to display the preprint in perpetuity.

It is made available under a CC-BY-NC-ND 4.0 International license .

53. Marck RE, van der Bijl I, Korsten H, Lorinser J, de Korte D, Middelkoop E. Activation, function and content of platelets in burn patients. Platelets. 2019;30(3):396-402.

54. Veraar C, Koschutnik M, Nitsche C, Laggner M, Polak D, Bohle B, et al. Inflammatory immune response in recipients of transcatheter aortic valves. JTCVS Open. 2021. 55. Dunn JLM, Kartchner LB, Stepp WH, Glenn LI, Malfitano MM, Jones SW, et al. Blocking CXCL1-dependent neutrophil recruitment prevents immune damage and reduces pulmonary bacterial infection after inhalation injury. Am J Physiol Lung Cell Mol Physiol. 2018;314(5):L822-L34.

56. Patel PJ, Faunce DE, Gregory MS, Duffner LA, Kovacs EJ. Elevation in pulmonary neutrophils and prolonged production of pulmonary macrophage inflammatory protein-2 after burn injury with prior alcohol exposure. Am J Respir Cell Mol Biol. 1999;20(6):1229-37.

\section{Data Availability Statement}

Raw data are available from the corresponding authors upon request.

\section{Competing Interests}

The authors have no conflicts of interest to declare.

\section{Funding}

This research project was funded by the Vienna Business Agency (Vienna, Austria; grant "APOSEC to clinic" 2343727) and by the Aposcience AG under group leader HJA. MM was funded by the Sparkling Science Program of the Austrian Federal Ministry of Education, Science and Research (SPA06/055).

\section{Author contributions}

Idea \& Conceptualization: HJA and ML; Data curation, ML, MTL, and TH; Formal analysis, ML and MTL; Funding acquisition, HJA; Investigation, ML, MTL, and TH; Project administration, HJA and TH; Resources, HJA and TH; Supervision, HJA and TH; Writing original draft, ML, HJA, and TH; Writing - review \& editing, MTL, DC, MD, KK, DB, AG, $\mathrm{BM}, \mathrm{CR}, \mathrm{SH}$, and MM. 
medRxiv preprint doi: https://doi.org/10.1101/2021.10.07.21264679; this version posted October 7, 2021. The copyright holder for this preprint (which was not certified by peer review) is the author/funder, who has granted medRxiv a license to display the preprint in perpetuity.

It is made available under a CC-BY-NC-ND 4.0 International license .

\section{Acknowledgements}

511 We thank the Dr. HP Haselsteiner and the CRISCAR Familienstiftung for their belief in this

512 private public partnership to augment basic and translational clinical research.

\section{Table}

516 Table 1. Study group demographics. ABSI abbreviated burn severity index, APACHE II acute

517 physiology and chronic health evaluation II, F:M female to male ratio, LOH length of

518 hospitalization, LOS length of stay at intensive care unit, SOFA sequential organ failure

519 assessment, TBSA total body surface area.

\begin{tabular}{|c|c|c|}
\hline & burn patients & controls \\
\hline $\mathrm{n}$ & 32 & 8 \\
\hline age in years * & $51.9(46.5) \pm 21.9[33-74]$ & $40.5(36) \pm 19.9[23-56]$ \\
\hline $\mathrm{F}: \mathrm{M}$ ratio [\%] & $10: 22(31.3: 68.7)$ & $3: 5(37.5: 62.5)$ \\
\hline TBSA $[\%] *$ & $32.5(30.0) \pm 19.6[16.3-39.5]$ & \\
\hline $\mathrm{LOH}[$ days $] *$ & $37.2(27.5) \pm 33.9[10.5-61.5]$ & \\
\hline LOS [days] $*$ & $29.7(19.5) \pm 33.0[7.3-35.3]$ & \\
\hline SOFA * & $6.8(6.5) \pm 3.6[5-9]$ & \\
\hline APACHE II * & $19.7(18.0) \pm 9.3[13.5-28.0]$ & \\
\hline ABSI & $7.91(8.0) \pm 2.8[5-9]$ & \\
\hline deceased $[\%]^{\S}$ & $6(18.8)$ & \\
\hline $3^{\text {rd }}$ degree burn $[\%]^{\S}$ & $22(68.8)$ & \\
\hline inhalation trauma [\%] $]^{\S}$ & $7(21.9)$ & \\
\hline
\end{tabular}




\section{Figures and figure legends}
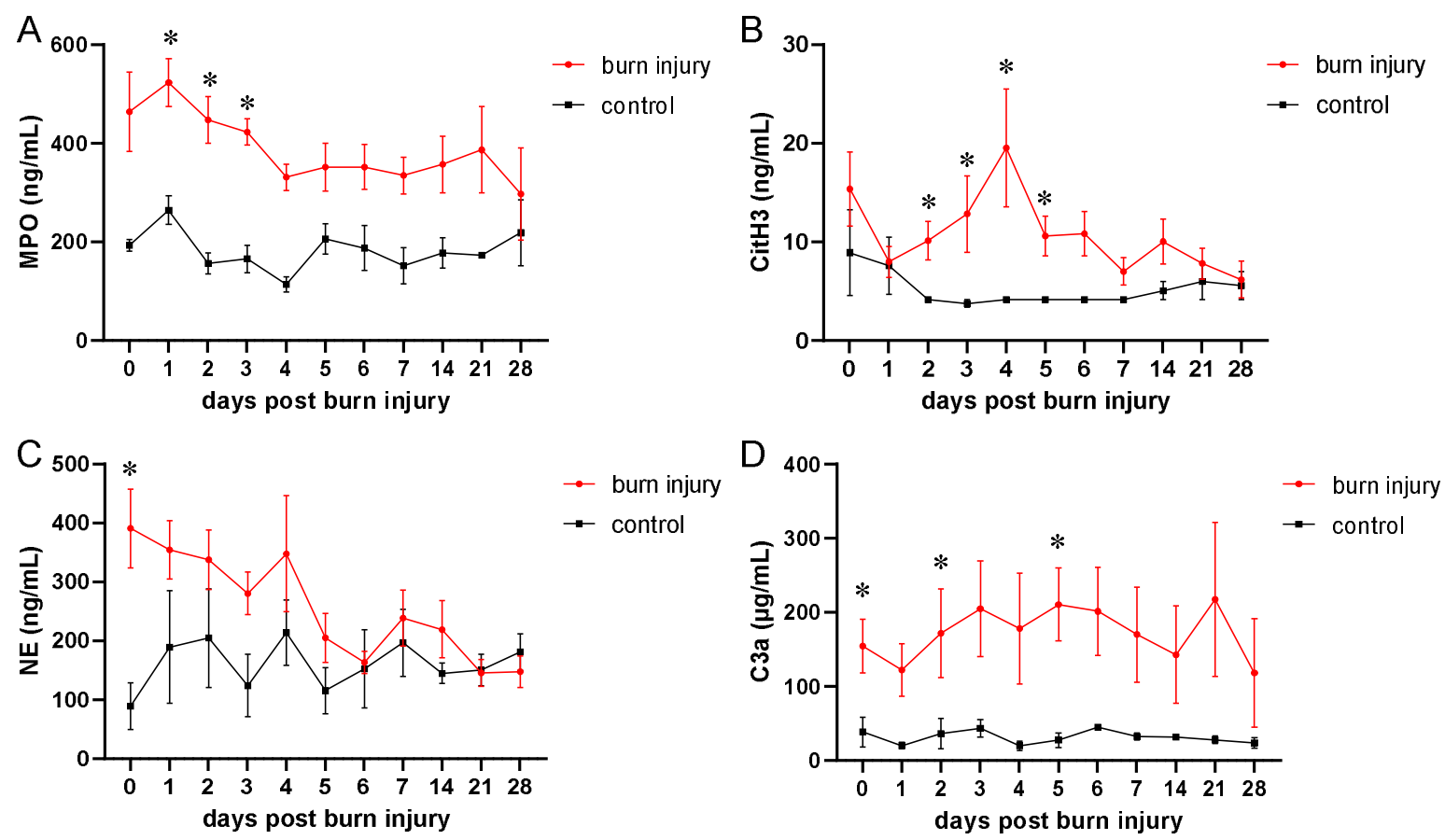

526 Figure 1. Elevated neutrophil-derived factors and C3a in burn sera. Systemic levels of (A)

$527 \mathrm{MPO}$, (B) CitH3, (C) NE, and (D) C3a were quantified in sera of burn victims and healthy

528 controls up to 4 weeks post injury. Data were compared by mixed effects analysis and Sidak's

529 multiple comparisons post hoc test. Data are presented as means \pm s.e.m. Asterisks indicate $p$

530 values <.05. 
A

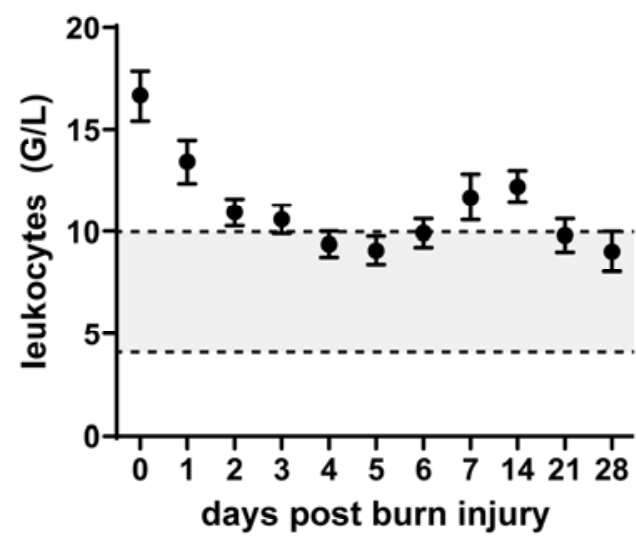

C
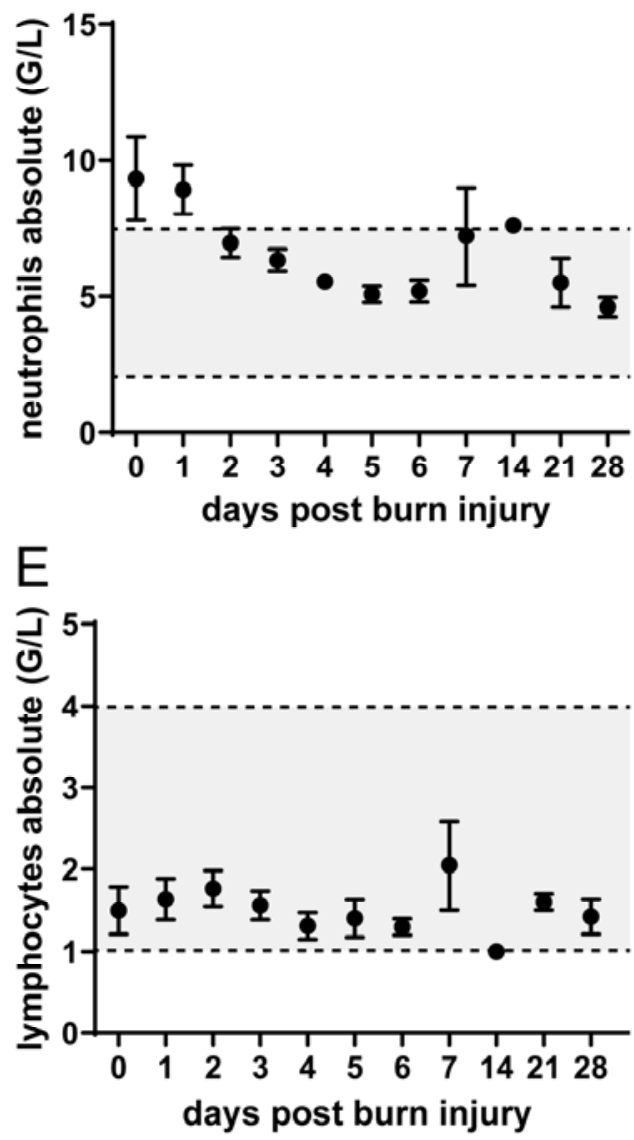

B

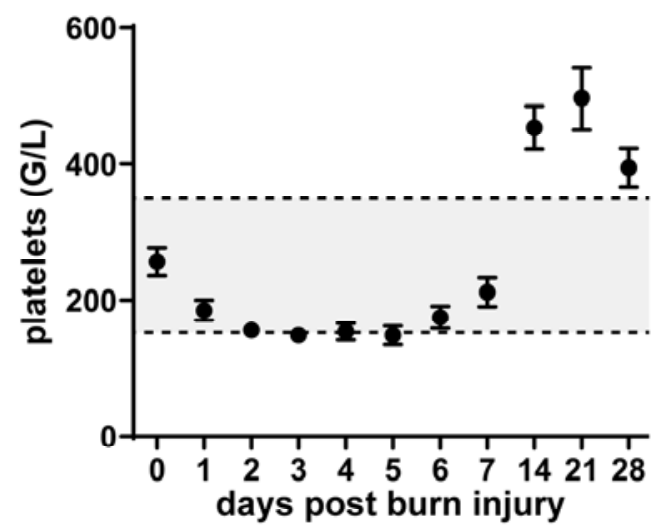

D

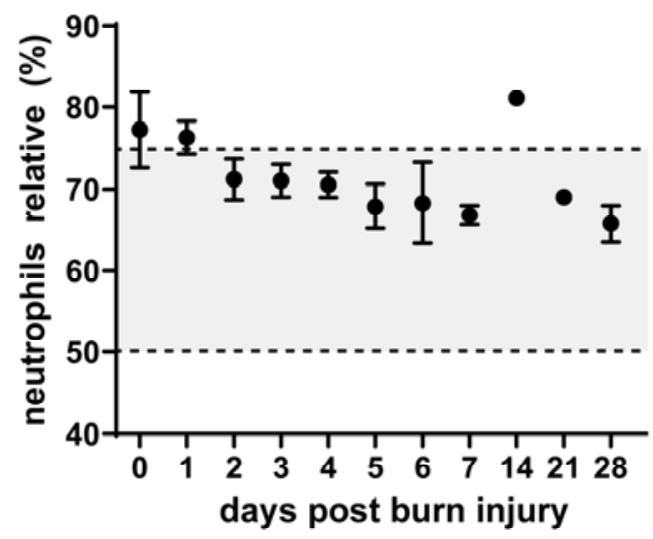

$\mathrm{F}$

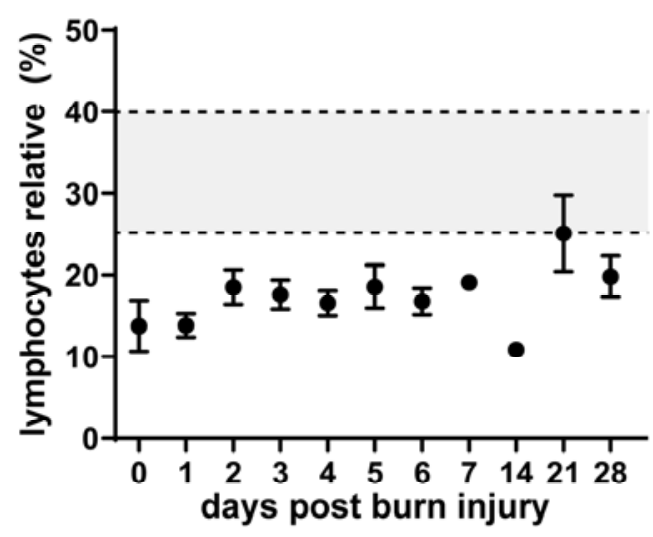

533 Figure 2. Immune cell counts up to 4 weeks post injury. Patient data in relation to established

534 in-hospital reference standards. Data are presented as means \pm s.e.m. 

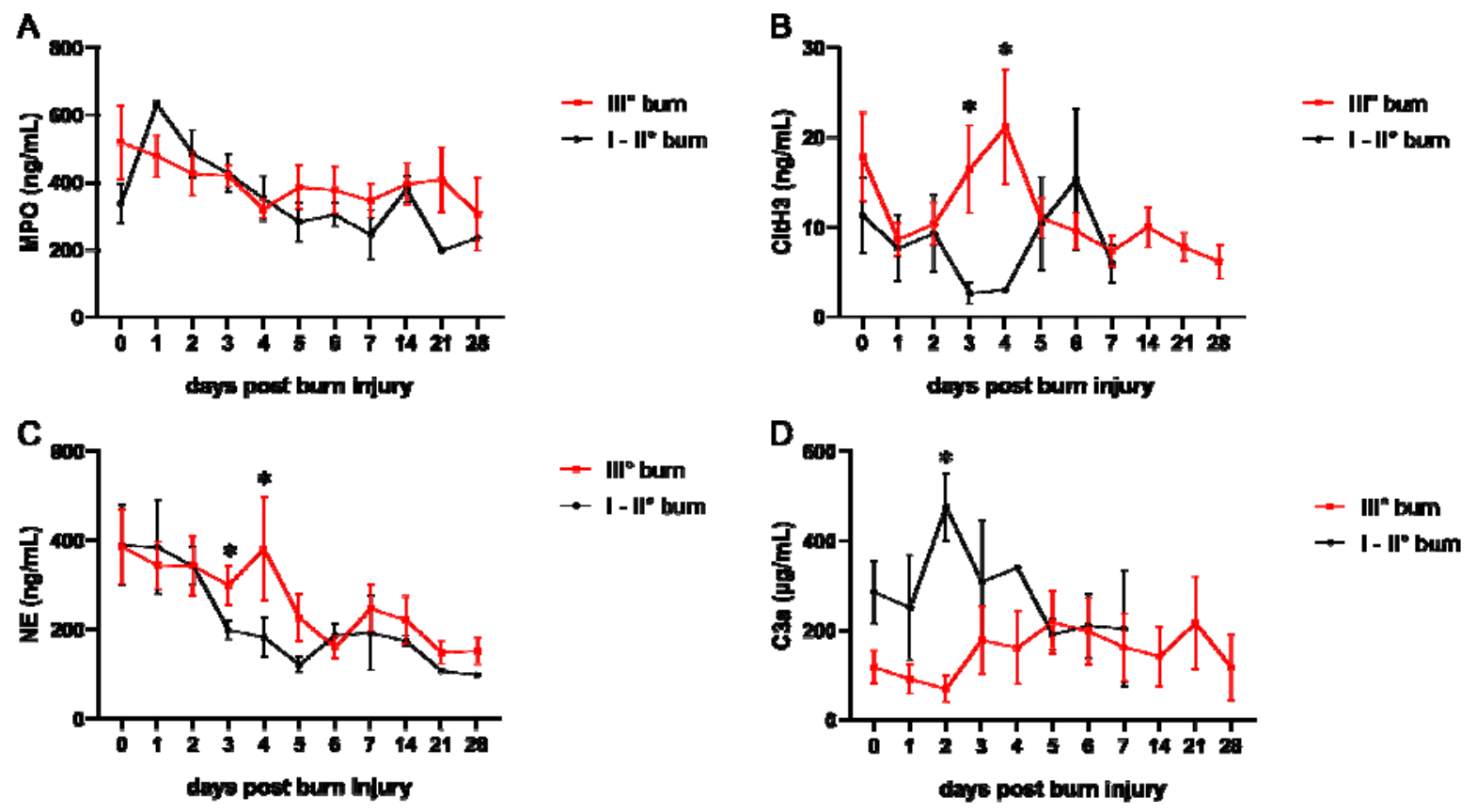

536 Figure 3. Increased NETosis in higher degree burns. Serum concentrations of (A) MPO, (B)

537 CitH3, (C) NE, and (D) C3a in $3^{\text {rd }}$ degree burn victims compared to lower degree burns. Data are 538 presented as means \pm s.e.m. * indicates $p$ values <.05. 

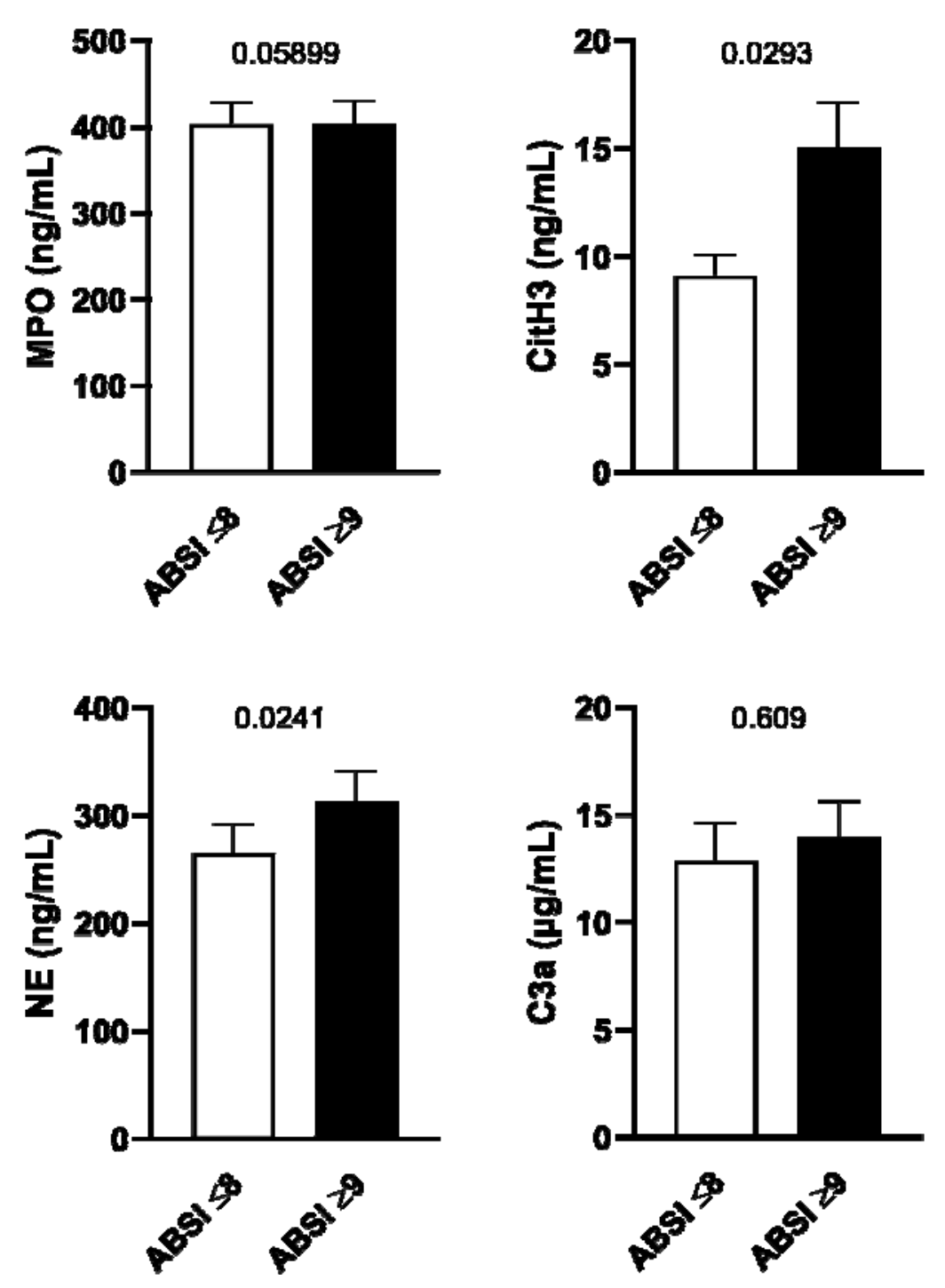

541 Figure 4. Serum concentrations of neutrophil-derived factors in low and high ABSI scores.

542 ABSI scores were determined on admission day and categorized into low $(\leq 8)$ and high $(\geq 9)$

543 values. Serum concentrations of MPO, CitH3, NE, and C3a of the first 7 days post admission

544 were compared. Data were statistically evaluated by Mann-Whitney test. 